\title{
A review of optimum parameter values of a passive solar still and a design for southern Bangladesh
}

\author{
Md. Nazmul Islam Sarkar ${ }^{*}$ (i), Anwarul Islam Sifat ${ }^{1}$, S. M. Shamim Reza ${ }^{2}$ and Md. Shibli Sadique ${ }^{3}$
}

\begin{abstract}
Pure and fresh water is being scarce day by day. Although Bangladesh is a riverine country, pure drinking potable water is not a cheap commodity. Most of the people in the cities boil water to drink, and people of the villages take tube-well's water directly, which might have high amount of heavy metal like arsenic. Solar still is a cheap and very useful renewable technology, which can be used in Bangladesh extensively everywhere at the rooftop as a pure water source. Objective of this paper was to find a low cost portable and easily maintainable passive solar still for southern part of Bangladesh. All the parameters of passive solar still are studied, and it is found that an inclined stepped solar still with passive condenser, internal and external reflectors, black cotton wick, and with optimum design values can be the desired still, which would give maximum yield. Finally, the optimum values of the parameters are used to propose a cheap design.
\end{abstract}

Keywords: Solar distillation, Desalination, Passive solar still, Parameters affecting still yield, Stepped still

\section{Background}

The concept of solar still is very useful in the context of supplying pure water to rural communities where there is scarcity of fresh water. In the disaster-prone countries like Bangladesh, solar still can be used as a lifesaving technology. It is cheap and easily constructible from rurally available materials. Although Bangladesh has so many rivers in its landscape, pure potable water is not available everywhere. Besides this, underground water of the southern districts is saline. Solar desalination can be one of the feasible solutions of this problem.

Solar stills can be classified under two broad categories: passive still and active still. In passive stills, the basin is heated directly without any active element like heaters or boilers and preheated water is also not flown from other sources. They have simple design, and no extra heating element is required. On the other hand, active heating elements are present in an active still. Preheated water can also be used. Passive and active stills can be further

\footnotetext{
*Correspondence: sarkarmni@gmail.com

1 Institute of Energy, University of Dhaka, Dhaka, Bangladesh Full list of author information is available at the end of the article
}

classified as efficient design or as conventional design. The classification is given in Fig. 1 (Singh et al. 1996).

The purpose of this paper is to provide a simple, cheap and efficient design of a passive solar still for southern Bangladesh. To do this, parameters affecting the distillate productivity of a passive solar still are studied from the literature, and optimum values are recorded to propose a high-yield design.

\section{Salinity level of Bangladesh}

Because of global warming and sea-level rise, salinity in the coastal area rises. This is a kind of disaster that occurs pretty slowly but has hazardous effects like increased soil salinity, increased ground water salinity and abandonment of agricultural fields. Inland fresh water lakes, ponds and aquifers are likely to be affected by saline and brackish water intrusion. Developing countries like Bangladesh are most vulnerable to this disaster. Figure 2 shows the soil salinity of Bangladesh in 2009 (SRDI 2016).

The blue line was the salinity boundary in 1973, which increased to the red line within 2000 and to the black line in 2009. It is evident from this figure that the salinity boundary is gradually increasing, and new lands are 


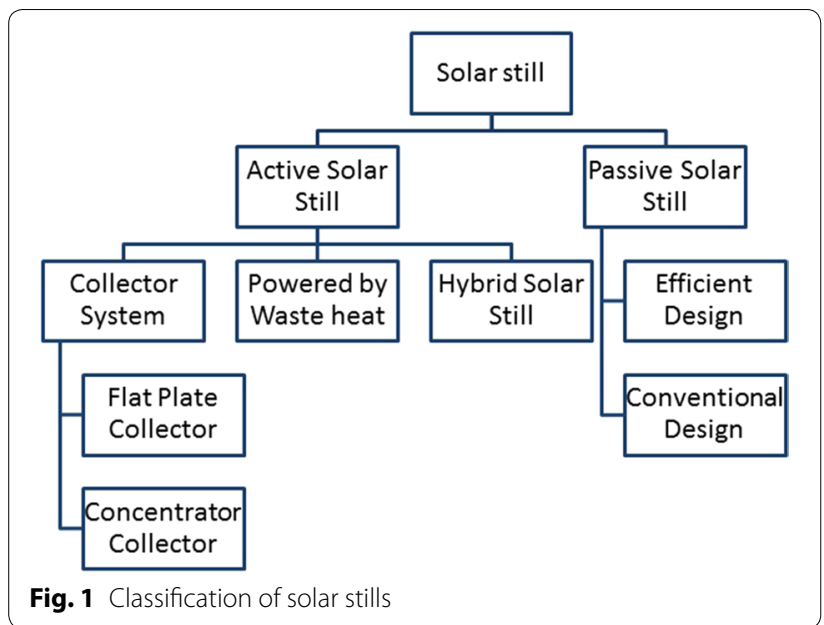

becoming saline day by day. As a matter of fact, the people living in between the salinity boundary area depends solely on surface water in the ponds or rain water. As most of them are poor and can not afford to buy potable drinking water, they suffer from severe waterborne diseases. After doing a field visit in 18 different locations in the Sundarban union of southern most Bagerhat district and taking water sample from the ponds of these locations, the water quality test is done. The detailed water quality test was conducted by Bureau of Research, Testing and Consultation (BRTC), and Bangladesh University of Engineering and Technology (BUET). The findings of this test are outlined in Table 1.

From Table 1, it is clear that most of the ponds have high amount of turbidity along with salinity and high $\mathrm{pH}$. Even though people of these areas are using this water for drinking and cooking, which have serious health effects.

To eliminate this problem, solar still along with rain water harvesting might be a very good solution. Passive solar stills are cheap and easily makable and also washable. They can be used for a long time without any maintenance. In the following sections, the optimum parameters are extracted for a passive solar still and a feasible design is proposed.

\section{Solar resource availability in Bangladesh}

In Bangladesh, average insolation level is pretty high from 4 to $5 \mathrm{kWh} /$ day around the year, which ensures the potential of solar power harvesting for solar still (NASA 2015). In Fig. 3, the 22 year's average of monthly averaged daily solar insolation and clearness index of Dhaka city is shown. The effectiveness of passive solar still mostly depends on the solar radiation received, and thus, Bangladesh is a very suitable place for solar still.

\section{Parameters affecting the productivity of a passive solar still}

Efficiency of a solar still mostly depends on the evaporation and condensation rate of the distillate water. According to Malik et al. (1982), the evaporative heat transfer can be given as:

$$
Q_{e, b . w-g . c}=h_{e, b . w-g . c} A_{b}\left(p_{b . w}-p_{g . c}\right)
$$

where the evaporative heat transfer coefficient from the basin water to glass cover is given as:

$$
h_{e, b . w-g . c}=\frac{M_{w} h_{f g} p_{T}}{M_{a} c_{p a}\left(p_{T}-p_{b . w}\right)\left(p_{T}-p_{g . c}\right)} h_{c, b . w-g . c}
$$

Dunkle (1961) has given the following formula for convective heat transfer:

$$
\begin{aligned}
h_{c, b . w-g . c}= & 0.884\left[\left(T_{b . w}-T_{g . c}\right)\right. \\
& \left.+\frac{\left(p_{b . w}-p_{b . c}\right)\left(T_{b . w}+273.15\right)}{\left(268900-p_{b . w}\right)}\right]^{\frac{2}{3}}
\end{aligned}
$$

From the above Eq. (1), it is clear that evaporative heat transfer from basin water to glass cover depends on the absorber plate area $\left(A_{b}\right)$ and the difference between partial pressure of the basin water temperature $\left(p_{b . w}\right)$ and partial pressure of glass cover temperature $\left(p_{g . c}\right)$. On the other hand, convective heat transfer from the glass cover to the atmosphere is given by Kalogirou (2005) as:

$$
Q_{c, g . c-a}=h_{c, g . c-a} A_{g . c}\left(T_{g . c}-T_{a}\right)
$$

where convective heat transfer coefficient is given by Watmuff et al. (1977) as:

$$
h_{c, g . c-a}=5.7+3.8 v
$$

From Eq. (4), it is evident that convective heat transfer from the glass cover to atmosphere depends on the area of the glass cover $\left(A_{g . c}\right)$ and temperature difference between glass cover $\left(T_{g . c}\right)$ and atmosphere $\left(T_{a}\right)$. From Eq. (5), it can be seen that the convective heat transfer coefficient depends on the wind velocity. Figure 4 shows a schematic diagram of a passive solar still where the energy flow from solar radiation to water is shown with different losses.

There are three types of parameters affecting the efficiency of a passive solar still: design parameters, operational parameters and climatic parameters. Among these climatic parameters are uncontrollable as they depend on the nature. But all the other parameters can be controlled to get the maximum distillate productivity. Now all the parameters will be discussed in brief to find out an efficient design. 


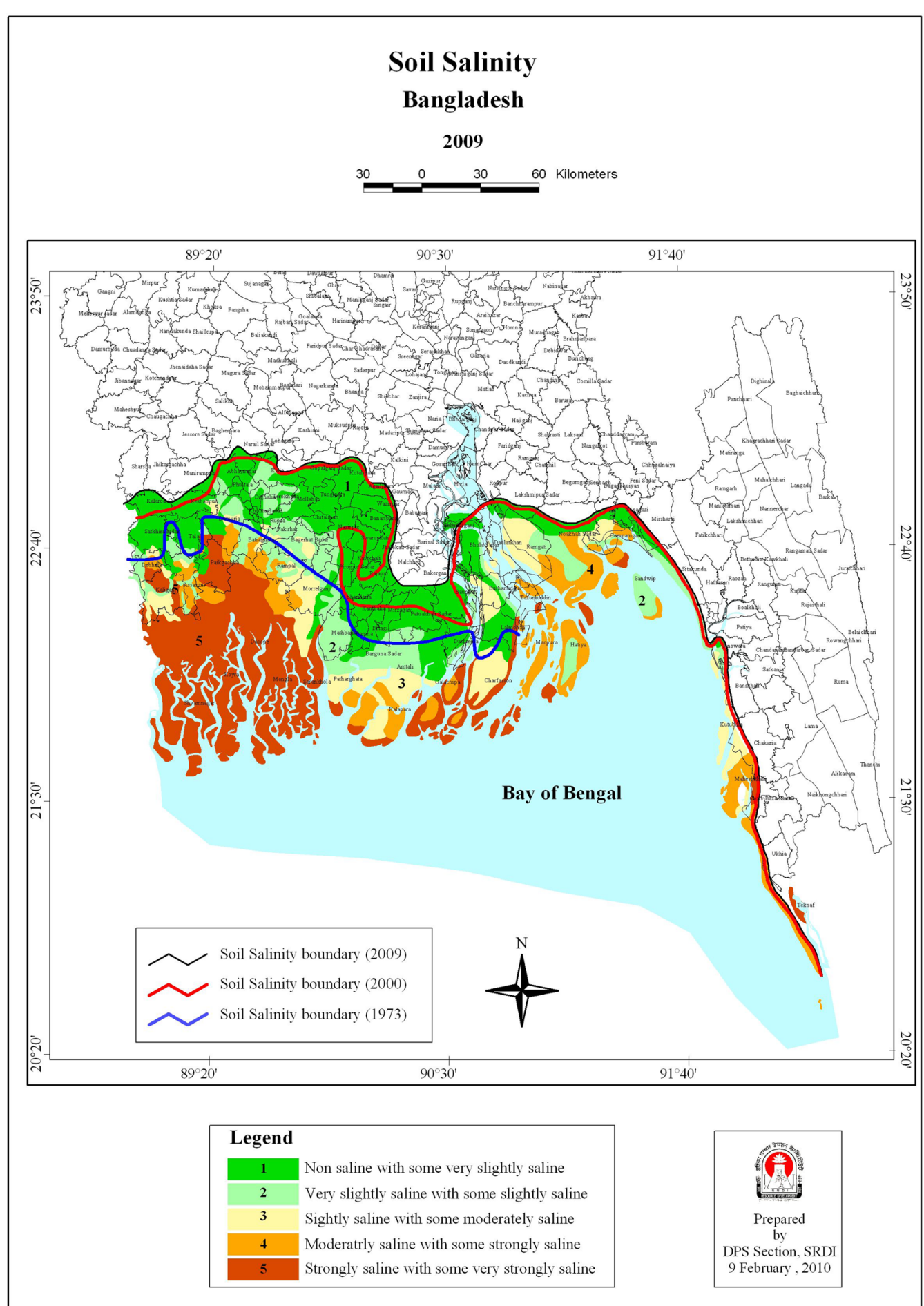

Fig. 2 Soil salinity of Bangladesh in 2009 (SRDI 2016)

\section{Design parameters}

The design parameters are mainly responsible for the efficiency of the solar still. In the following section, the design parameters are discussed in brief:

\section{No. of slopes}

Passive solar still can have single-slope glass cover basin or double-slope basin. Garg and Mann (1976) conducted a research on climatic, design and operational parameters 
Table 1 Water quality test results of 18 ponds of Bagerhat district

\begin{tabular}{|c|c|c|c|c|c|}
\hline S no. & Pond name & Turbidity (NTU) & Salinity (ppm) & $\mathrm{pH}$ & Usage \\
\hline 1 & Madurpalta Niaz Makhdum Pond, Sundarban Union & 32.7 & 2.1 & 8.04 & Drinking and cooking \\
\hline 2 & Mahaldar Bari Pond, Sundarban Union & 5.24 & 1.3 & 8.13 & Drinking and cooking \\
\hline 3 & Harun Khandaker's Pond, Sundarban Union & 35.7 & 2.7 & 8.01 & Cooking \\
\hline 4 & Abdur Rashid's Pond, Chila Union & 38.3 & 3.5 & 8.4 & Cooking \\
\hline 5 & Pijush-Depicho Pond, Chila Union & 6.62 & 2.9 & 8.25 & Drinking and cooking \\
\hline 6 & Kakoli's Pond, Chila Union & 27.6 & 3 & 8.2 & Cooking \\
\hline 7 & Perikhali Bazar Pond, Perikhali Union & 37.5 & 0.6 & 7.6 & Cooking \\
\hline 8 & Alok Mondal's Pond, Kalikabari Union & 72.1 & 0.9 & 8.01 & Cooking \\
\hline 9 & Andharia Masjid Pond-1, Sundarban Union & 14.3 & 1.5 & 8.12 & Drinking and cooking \\
\hline 10 & Andharia Masjid Pond-2, Sundarban Union & 17.6 & 1.1 & 7.9 & Drinking and cooking \\
\hline 11 & Amratola Pond, Sonailtola Union & 16.1 & 1.6 & 8.13 & Cooking \\
\hline 12 & Gachi Pond, Sonailtola Union & 53.6 & 0.7 & 8.5 & Cooking \\
\hline 13 & Ghorami Pond, Chila Union & 9.67 & 1.5 & 7.71 & Cooking \\
\hline 14 & Kalipodo Pond, Chila Union & 81.7 & 0.3 & 7.49 & Cooking \\
\hline 15 & Sunil Mondal Pond, Chila Union & 63.8 & 0.7 & 7.53 & Drinking and cooking \\
\hline 16 & Bimol's Pond, Haldibuniya, Chila Union & 16 & 0.9 & 8.18 & Drinking and cooking \\
\hline 17 & Shikhor Paroi's Pond, Chila Union & 11.1 & 1.6 & 8.21 & Cooking \\
\hline 18 & Hurka Pond, Hurka Union & 37.5 & 0.6 & 7.6 & Cooking \\
\hline
\end{tabular}

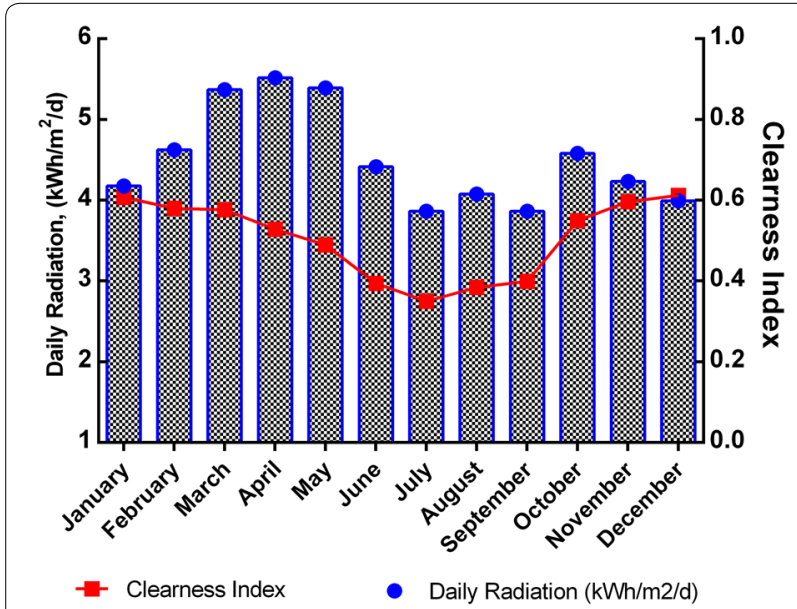

Fig. 3 Monthly averaged daily solar insolation with superimposed clearness index (NASA 2015)

on single-sloped and double-sloped solar still, and they found that single-sloped solar stills receive higher solar radiation than double-sloped basins. So the desired still should be a single-slope still.

\section{Number of basins}

There are single- and multi-basin solar stills. A research done by Al Mahdi (1992) shows that double basin gives higher yield than single basin stills. If the number of basin is increased further to three or four, then distillate productivity does not increase that much. Although the double basin still has higher productivity, the design of double basin is harder to implement and the portability is immensely reduced. So number of basins can be limited to one in the context of easy making of the still.

\section{Basin liner construction}

El-Naggar et al. (2016) have done the experimental and theoretical performance analysis of finned-single effect solar still. They have used finned-basin liner and found an efficiency improvement of around $13 \%$.

\section{Inclination of glass cover}

The distillate productivity depends heavily on the amount of solar radiation it receives. So tilt angle of the solar still is a very important parameter to consider. If we want to receive normal solar radiation, then its tilt angle should be equal to the latitude of the place. El-Maghlany et al. (2016) have studied the effect of glass cover inclination angle on conventional solar still. They have found that proper glass cover inclination angle can improve the still productivity up to $22.3 \%$. El-Samadony et al. (2016) have also studied the influence of glass cover inclination angle on radiation heat transfer rate within stepped solar still, and they found that taking radiation shape factor into account is very important at low solar insolation. A numerical analysis was conducted by Singh and Tiwari (2004), and they found that maximum annual distillate happens if the glass tilt angle is equal to the latitude of the place. Therefore, the proposed still should have an inclination of glass tilt angle equal to the latitude of the place. For example for Dhaka city, it would be equal to $23.7^{\circ}$. 


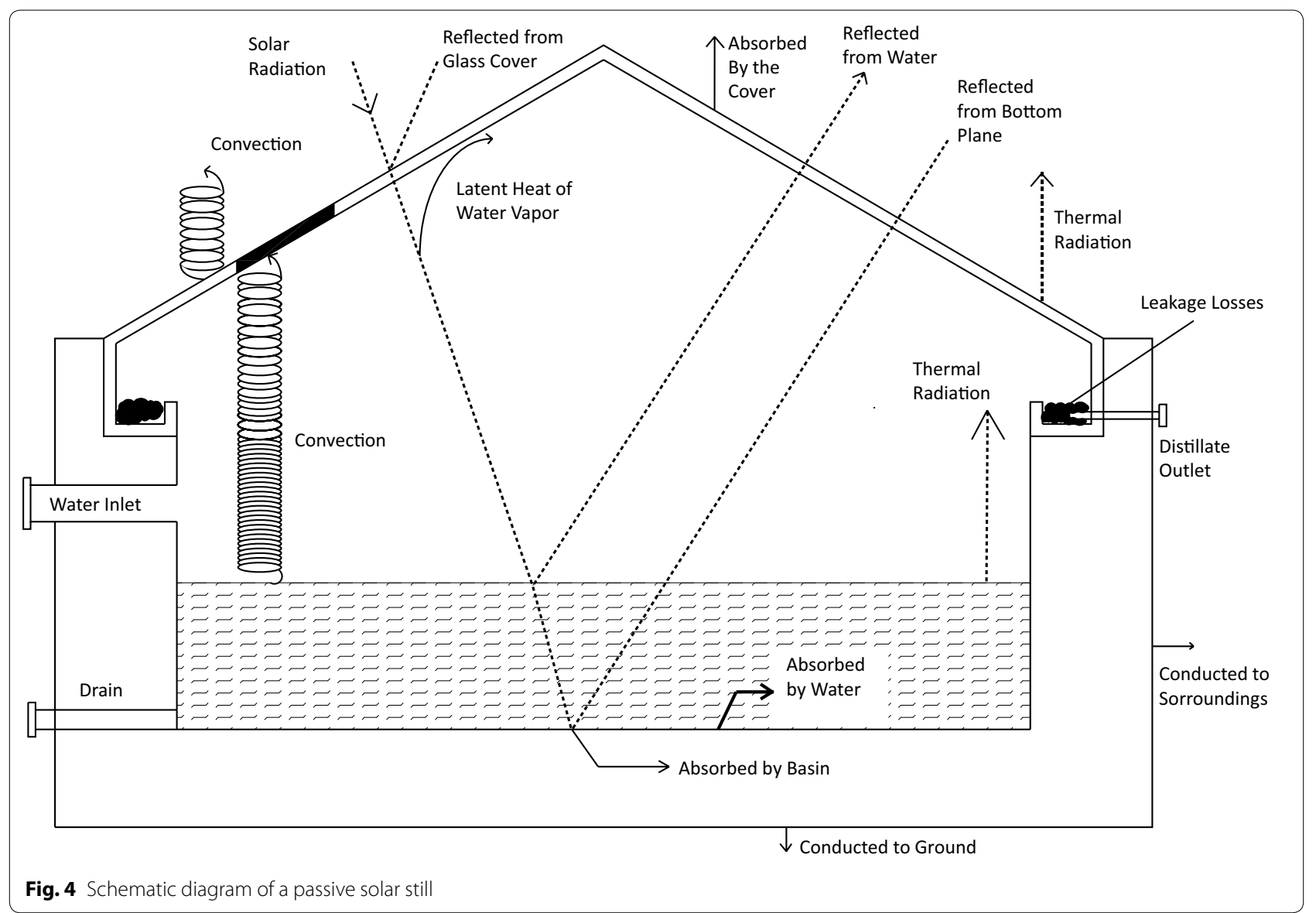

\section{Glass cover thickness}

For solar distillation, glass is the suitable material as it has higher transmittance for solar radiation of various angles. Glass has also a longer life, and it can easily create a temperature difference on the top and bottom of the cover. From Eqs. (3) and (4), it can be seen that with increase in glass cover thickness the temperature difference between the water and glass cover surface will increase, which will eventually increase the distillate productivity. However, the heat transfer rate will also decrease at the same time, which will reduce the distillate productivity. Ghoneyem and Ileri (1997) showed in their research that $16.5 \%$ more production is possible if $3-\mathrm{mm}$ glass thickness is used than 6-mm glass thickness. So the glass thickness should be kept less than or equal to $4 \mathrm{~mm}$.

\section{Gap distance between water and glass cover}

The gap distance between the water surface and glass cover can have significant impact on distillate productivity. Ghoneyem and Ileri (1997) analyzed solar stills with different glass cover to water gap distance and found an increase of $11 \%$ distillate productivity if the gap is reduced from 13 to $8 \mathrm{~cm}$. In the desired still, the gap distance should be kept as low as possible, which might be 8 $\mathrm{cm}$ or lower. To reduce the gap distance to minimum, a stepped solar still can be used.

\section{Stepped solar still}

In conventional basin-type still, the gap distance and water depth cannot be maintained at minimum level as the basin area is large and the angle of inclination of the glass cover creates a huge gap between the cover and the basin. This problem can be eliminated by using small trays on an inclined basin. This is called stepped solar still. Velmurugan et al. (2008) have done a performance analysis for productivity enhancement of stepped solar still, and they increased the output by $98 \%$. Kabeel et al. (2012) experimented stepped solar still with varying water depth of trays and width, and they found that at $5 \mathrm{~mm}$ water depth and $120 \mathrm{~mm}$ width of the trays the yield is maximum which is $53.7 \%$ higher than conventional still. So $4-5 \mathrm{~mm}$ water depth and $100-120 \mathrm{~mm}$ tray width should be used for the proposed still. Figure 5 shows a schematic diagram of a stepped solar still.

\section{Energy absorption and storing materials}

Black materials like black gravel, black rubber, charcoal, black volcanic rock, uncoated or coated metallic wiry 


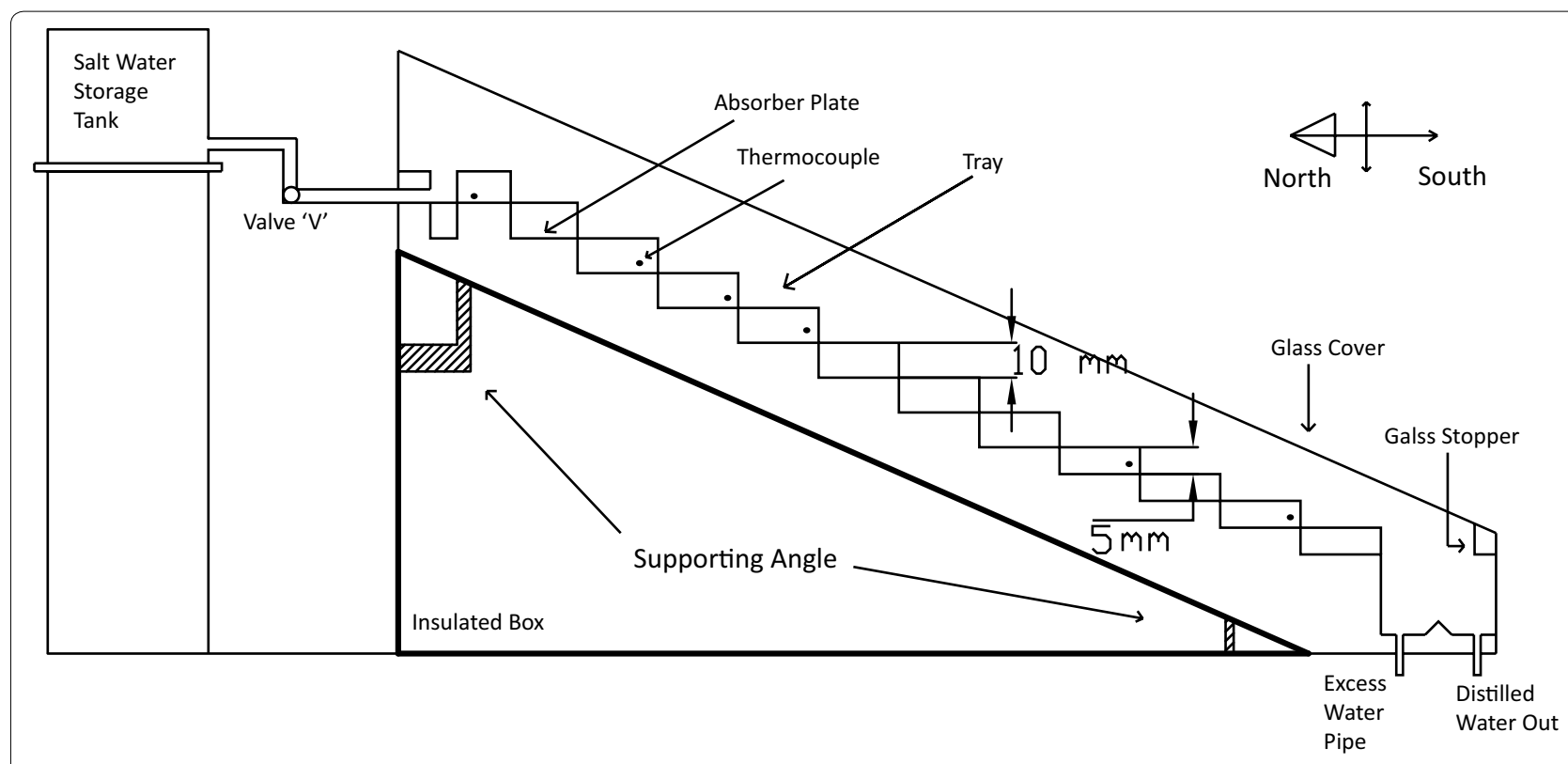

Fig. 5 Schematic diagram of a stepped solar still (Dunkle 1961)

sponge or black-painted aluminum fins can store more heat and also increase the heat absorptivity of the basin. In a study, black volcanic rock is found to be a better absorbing material than both coated and uncoated metallic wiry sponge (Abdallah et al. 2009). Patel and Kumar (2016) have done a comparative performance evaluation of modified passive solar still using heat storage material and found that distillate productivity can be improved by $11.24 \%$ by using energy-storing materials. According to Cooper (1972), surface reflectance is more disadvantageous than linear reflectance because of the absorbing properties of basin water. Therefore, charcoal, black gravel or rock will increase the energy supplied by increasing the absorbed solar radiation in water. As charcoal is easily available and cheap in the context of Bangladesh, it can be used as energy storage material in the proposed still.

\section{Insulation thickness}

As significant heat is lost due to low or no insulation thickness, the solar still should be properly insulated. The higher the insulation, the lower the heat loss. Cotton, clothes, rubber, glass wool, mica sheets, wood, etc. can be good insulation material. But among them rubber is the most used and efficient insulation material. The effect of insulation thickness was investigated by Garg and Mann (1976). They found that $26 \%$ of heat is lost through the base of the basin, which can be recovered by using cheap saw dust as insulation ( $25 \mathrm{~mm}$ thick), and thus, $7 \%$ distillate productivity can be increased. Al-Karaghouli also investigated the influence of insulation thickness on single and double basin stills and found the efficiency to be increased by $2-4 \%$ when side of the basin is insulated (Al-Karaghouli and Alnaser 2004). Al-Hinai et al. (2002) have shown that optimum insulation thickness should be of $0.09-0.13 \mathrm{~m}$. Therefore, insulation thickness of $0.10 \mathrm{~m}$ can be used in the proposed still.

\section{External and Internal Reflectors}

Internal and external reflectors can be added to increase the solar radiation on the still, which will eventually increase the distillate productivity. According to the theoretical analysis done by Tanaka and Nakatake (2006), it is evident that distillate output can be increased up to $48 \%$ when internal and external reflectors are added. Hiroshi Tanaka had also done an experimental analysis of a basintype still with internal and external reflectors in winter at Japan, which showed the similar outcome (Tanaka 2009). He also had done a theoretical analysis of basin-type solar still with flat plate external bottom reflector where an increase of $25-65 \%$ of distillate production was expected (Tanaka 2011). According to these analyses, the proposed still should have both external suspended reflectors and internal reflectors in the basin liner.

\section{Sun tracking system}

Tracking the sun is the best way to increase the incident solar radiation on the still. Distillate productivity will increase significantly if sun trackers are used. There are two types of sun tracker: single-axis and dual-axis trackers. Single-axis trackers tracks the sun only from east to west, but dual-axis trackers tracks the exact location of the sun on a particular day at a particular time. So in 


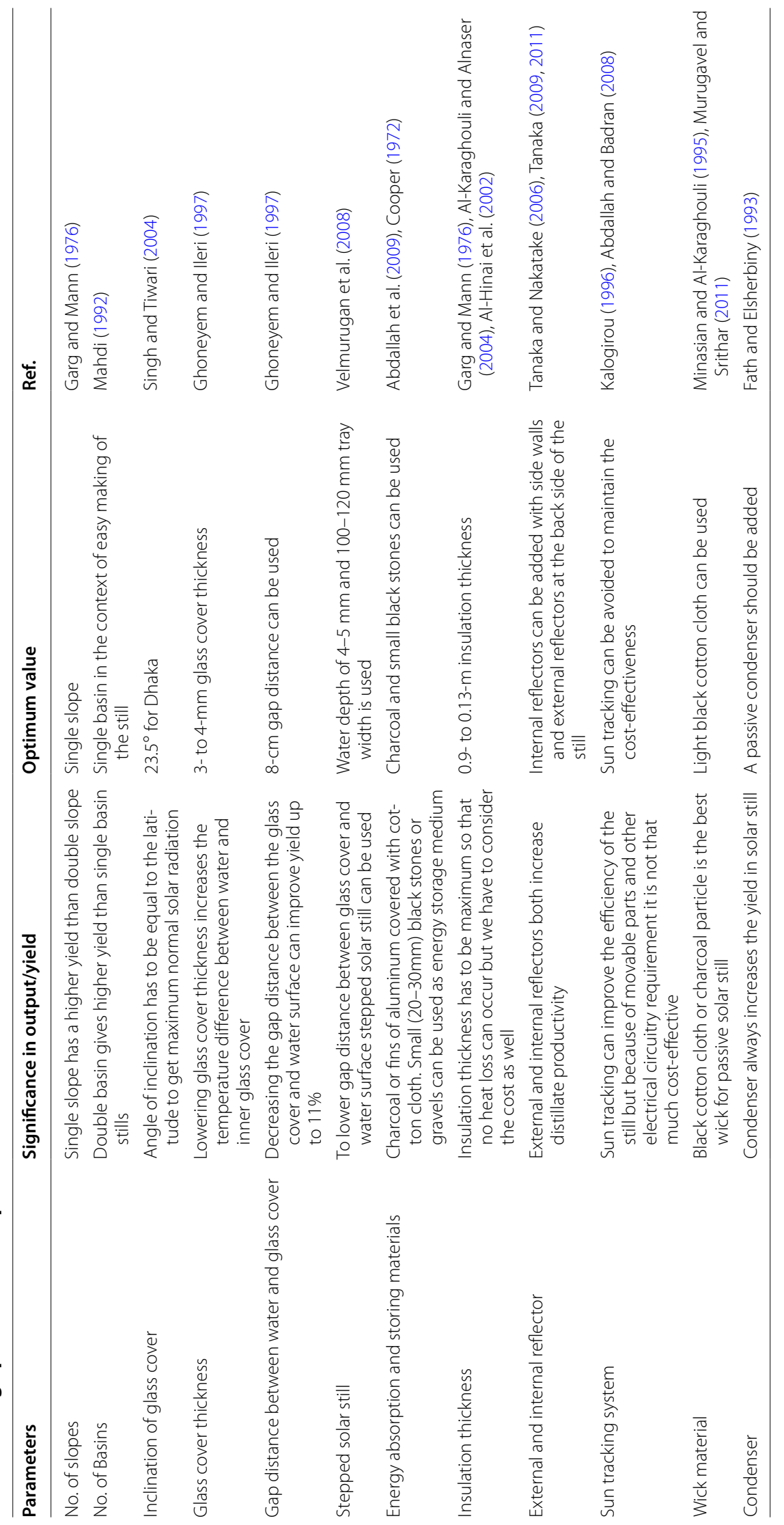




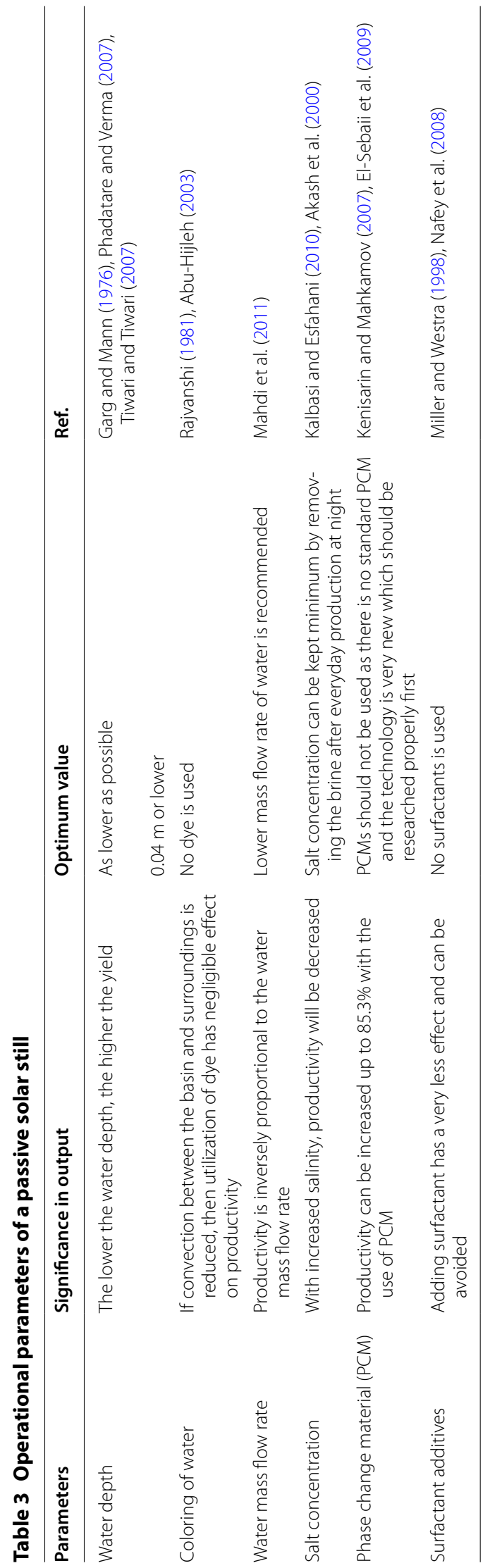


Table 4 Climatic parameters of a solar still

\begin{tabular}{|c|c|c|c|}
\hline Parameters & Significance in output & Optimum value & Ref. \\
\hline Solar radiation & $\begin{array}{l}\text { The higher the input solar radiation, the } \\
\text { higher the output of the still }\end{array}$ & $\begin{array}{l}\text { The still should be placed on an open } \\
\text { space with ample sunlight availability }\end{array}$ & Singh et al. (1996), Garg and Mann (1976) \\
\hline Wind speed & $\begin{array}{l}\text { In summer, only wind speed has a posi- } \\
\text { tive effect on the still's productivity }\end{array}$ & $\begin{array}{l}\text { We can place our still at a place where it } \\
\text { will receive high wind at summer and } \\
\text { low wind at winter }\end{array}$ & El-Sebaii (2000), Soliman (1972) \\
\hline Ambient temperature & $\begin{array}{l}\text { Ambient temperature of } 10^{\circ} \mathrm{C} \text { will } \\
\text { increase the yield up to } 8.2 \%\end{array}$ & $\begin{array}{l}\text { We should place the still in a place } \\
\text { where there is no shadow and has a } \\
\text { high ambient temperature }\end{array}$ & Al-Hinai et al. (2002) \\
\hline Dust and cloud cover & $\begin{array}{l}\text { Dust and cloud cover always reduce the } \\
\text { yield of the still }\end{array}$ & Dust can be cleaned time to time & Hegazy (2001), Velmurugan et al. (2008) \\
\hline
\end{tabular}
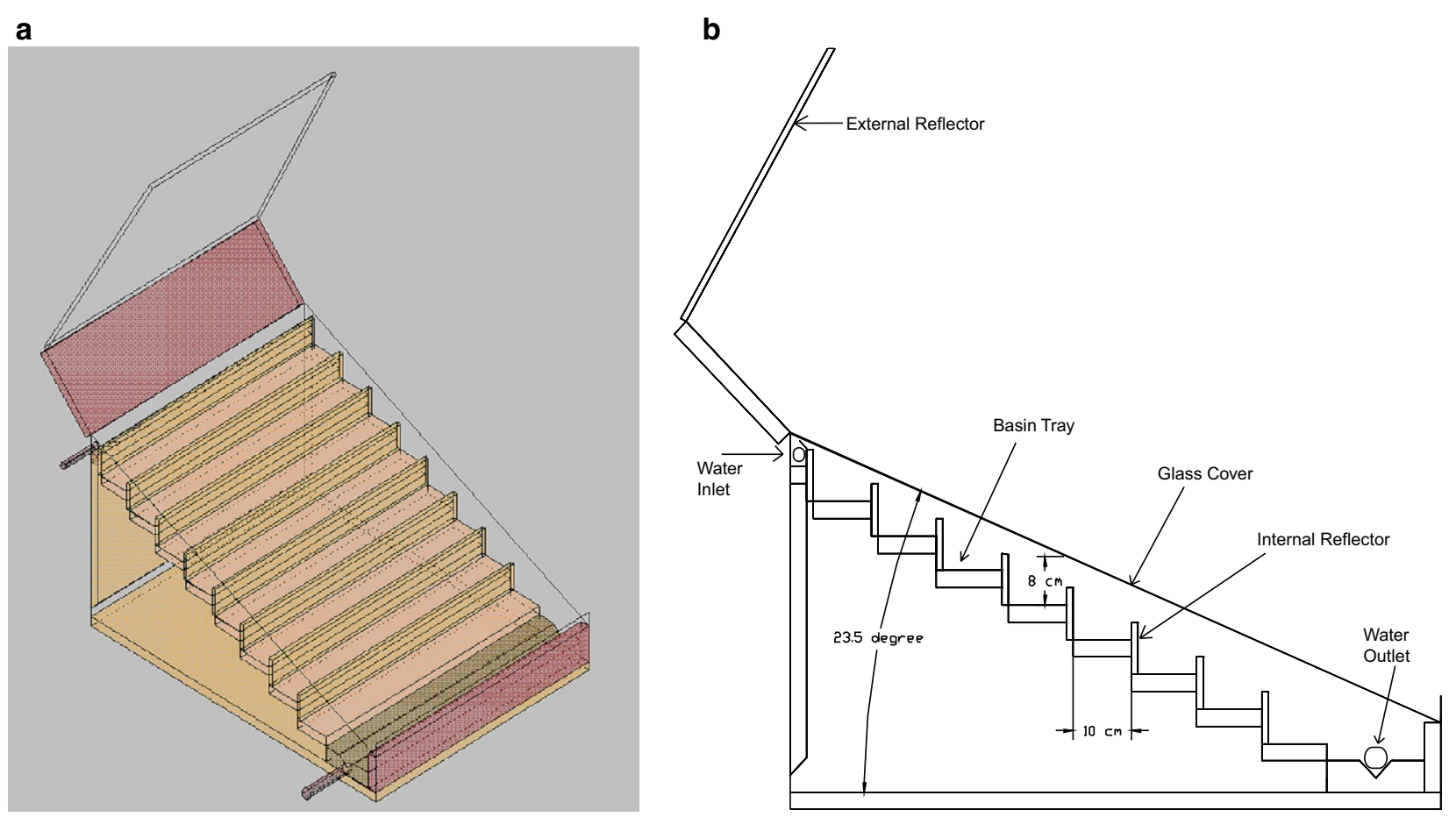

Fig. 6 a Three-dimensional design and $\mathbf{b}$ design with dimension values of the proposed solar still

dual-axis trackers the basin is always perpendicular to incident sun rays. Kalogirou (1996) has shown a design of a single-axis sun tracking system. Abdallah and Badran (2008) researched about a sun tracking system for productivity enhancement of solar still, and they found the increase in overall efficiency of $2 \%$ of the still, which increases the productivity up to $22 \%$. Therefore, in the proposed still sun tracking system can be added. However, to maintain the simplicity of the design only the single-axis one-step azimuth tracker can be used.

\section{Wick material}

Water surface area is an important parameter of still productivity. By using wick material, we can increase the exposed surface area of water. Minasian and AlKaraghouli (1995) combined both wick-type and basintype still to improve performance of the still. They found that overall efficiency has been increased $85 \%$ more than basin-type still and $43 \%$ more than wick-type still. Hansen et al. (2015) have done the performance analysis on inclined solar still with different new wick materials and wire meshes. They compared the performances of different wick materials like wood pulp, paperwick, wickingwater coral fleece fabric and polystyrene sponge. They achieved maximum distillate of $4.28 \mathrm{l} /$ day using water coral fleece with weir mesh-stepped absorber plate. Murugavel and Srithar (2011) used different wick materials like black cotton cloth, jute cloth, sponge sheet, coir 
mate, etc. and found light black cotton cloth as the most efficient one. Therefore, light black cotton cloth can be used as wick material for the proposed still.

\section{Condenser}

Condensation rate is a very important factor affecting the distillate productivity. Fath and Elsherbiny (1993) studied the effect of adding a passive condenser on the performance of basin-type still, and they found that $70 \%$ of the yield is increased when a condenser is used. Bhardwaj et al. (2016) have showed the effect of adding a plastic channels as passive condenser on an inflatable solar still. They found the production of water achieved from the still at a water temperature of $73{ }^{\circ} \mathrm{C}$ to be $0.75 \mathrm{l} / \mathrm{h}$ which is much higher than a conventional still. So a passive condenser can be added in the design of the proposed still.

Table 2 summarizes all these design parameters.

\section{Operational parameters}

These parameters have to be controlled at the time of operation. A proper user manual should be accompanied with the solar still, which will indicate the optimum operational parameters. Below these parameters are discussed in brief.

\section{Water depth}

The depth of water level has significant influence on the distillate productivity. Garg and Mann (1976) experimented that output of a still decreases with increase in depth of water level in the still. Phadatare and Verma (2007) also got the similar result when they experimented with plastic solar stills with different water depths. Tiwari and Tiwari (2007) found that lower water depth such as 0.02-0.04 $\mathrm{m}$ has higher annual efficiency up to $44 \%$ compared to higher water depth such as $0.18 \mathrm{~m}$. So the proposed still would have minimal water depth. The value can be at maximum $0.04 \mathrm{~m}$.

\section{Coloring of water}

Most of the heat from solar radiation is not absorbed by the clear water, rather it is absorbed by the basin's bottom surface. So mixing dye with water will make the water to absorb most of the heat from solar radiation. Rajvanshi (1981) has done an analytical and experimental study of the effect of adding dyes to a solar distillation unit and found that addition of water soluble dyes increases the productivity by as much as $29 \%$ and among the dyes tested black naphthylamine dye was the most suitable one. Abu-Hijleh (2003) discovered that if convection between the basin and surroundings is reduced distillate output can be improved from 42 to $54 \%$, and then, utilization of dye will have negligible effect on the distillate productivity. Thus, the use of dye that might have hazardous health effects can be avoided without sacrificing the efficiency.

\section{Water mass flow rate}

Water flow rates inside the basin has significant effect on the distillate productivity. Mahdi et al. (2011) have done experimental tests to determine the correlation between productivity and water flow rates, and they found the productivity to be inversely proportional to the water mass flow rates in a tilted-wick-type still. So a lower mass flow rate of water should be maintained in the proposed still.

\section{Salt concentration}

The salinity of the water can have significant effect on still production. Kalbasi and Esfahani (2010) experimented the effect of salt concentration by varying the salt concentration of water. Increasing the salinity from 0.5 to $3.5 \%$ leads to $20 \%$ reduction in the yield. Akash et al. (2000) also researched the effect of salt concentration on the distillate productivity, and they also found similar type of result, which indicates that with increasing salinity productivity will be decreased. So the salinity level of water should be kept as low as possible. Although it is not possible to control the salinity of sea water, proper maintenance of the still like cleaning the still each week regularly can lower the salinity to a significant value.

\section{Phase change material (PCM)}

Phase change materials (PCM) have high heat of fusion and can release large amounts of energy while melting or solidifying (Kenisarin and Mahkamov 2007). El-Sebaii et al. (2009) have shown in their research that daily productivity can be increased up to $85.3 \%$ with the use of PCM. Asbik et al. (2016) have done the exergy analysis of solar still combined with PCM. Kenisarin and Mahkamov (2007) studied the process of storing solar energy using PCMs. Among organic PCMs there are fatty acids like carpic acid (655 mol\%) + lauric acid (35 mol\%) (Dimaano and Watanabe 2002), lauric acid (62.6 wt\%) + myristic acid (37.4 wt\%) (Kauranen et al. 1991), and myristic acid $(64.0 \mathrm{wt} \%)+$ stearic acid (36.0 wt\%) (Sarı 2005). Among inorganic PCMs salt hydrates, manganese nitrate hexahydrate (Nagano et al. 2003), and magnesium nitrate hexahydrate (Nagano et al. 2004) are usually used. However, as there is no standard PCM and the technology is very new, PCMs should not be used in the proposed still.

\section{Surfactant additives}

Surfactants are specialized type of additives used to change the surface properties of water by reducing surface tension and skin friction and by enhancing boiling heat transfer (Miller and Westra 1998). Examples of 
surfactants can be sodium lauryl sulfate (SLS) (Nafey et al. 2008), sodium dodecylbenzene sulfonate (Zhang et al. 2003), and poly(oxyethylene tridecyl ether) or PTE (Park et al. 2010), etc. Nafey et al. (2008) have done the enhancement of solar distillation process by surfactant additives. They have found that the yield increases by $0.7,2.5,4.7$, and $7 \%$ at additive concentrations of 50,100 , 200 , and $300 \mathrm{ppm}$, respectively, but addition of more surfactant, i.e., $400 \mathrm{ppm}$, will reduce the yield by $6 \%$. Therefore, it is evident that adding surfactant has a very less effect, which can be avoided.

\section{Addition of nanoparticles}

Performance of the passive solar still is improved by adding nanoparticles in varying water depth (Gupta et al. 2016). It was found in the study that compared to conventional passive solar still the performance has improved. Sharshir et al. (2016) also added graphite nanoparticles and found an improvement of $50.28 \%$ in still productivity.

\section{Preheating of water}

Mishra et al. (2016) have done the mathematical modeling and evaluation of solar still for utilization of hot wastewater. From their study, it was evident that utilization of waste heat from thermal power system or chiller units to preheat the water of the still significantly improves the productivity. Yari et al. (2016) have integrated semitransparent photovoltaic and evacuated tube collector in natural mode to heat the water and get electrical power from the photovoltaic panels. Theoretical and experimental investigation of a glass basin solar still with integrated preheated water supply was done by Rajaseenivasan et al. (2016). Their study reveals that increase in water depth in preheater section reduces the day time productivity but considerably enhances the nocturnal productivity of the glass basin solar still.

Table 3 summarizes all these operational parameters.

\section{Climatic parameters}

These parameters cannot be controlled and solely depend on the climate condition. At least what can be done is a proper place can be chosen, and proper maintenance mechanisms can be added to achieve the maximum performance. These parameters are discussed below:

\section{Solar radiation}

Solar radiation is the most vital parameter of solar distillation unit as it is the energy source of the still. A lot of researches have shown that solar still productivity is directly proportional to incident solar radiation (Singh et al. 1996; Garg and Mann 1976). The solar radiation cannot be controlled, but it can be placed at a proper place where it will get ample sunshine during whole year.

\section{Wind speed}

The difference of temperature between glass inner surface and water has a significant impact on distillate productivity. Wind flow can increase that temperature difference, which can eventually increase the yield. According to ElSebaii (2000), daily productivity increases with increase in wind flow up to a certain wind speed but has no significant affect after that speed and the effect of wind is more at summer and at higher water masses. For his experimented stills, that optimum speed was found to be 10 and $8 \mathrm{~m} / \mathrm{s}$ on typical summer and winter days, respectively. Soliman (1972) has also researched on the effect of wind on solar distillation. He found that at lower ambient temperature increasing wind speed increases the temperature difference between water and glass cover of the still. This will eventually increase radiation, conduction and convection losses at higher rate than the increase in rate of evaporation. The scenario is opposite at higher temperature. Therefore, the still can be placed at a place where it will receive high wind at summer and low wind at winter.

\section{Ambient temperature}

Ambient temperature has direct impact on still's productivity. The higher the temperature, the higher the yield. Al-Hinai et al. (2002) have shown that increasing ambient temperature of $10{ }^{\circ} \mathrm{C}$ will increase the yield up to $8.2 \%$. Thus, the still should be placed where there is no shadow and has a high ambient temperature.

\section{Dust and Cloud Cover}

Accumulation of dust on the glass cover of the still decreases the transmittance of the glass cover significantly, which will eventually decrease the distillate productivity. Cloud cover reduces the direct component of the solar radiation to a significant amount and lowers the yield. Hegazy (2001) experimented the effect of dust accumulation on solar transmittance through glass covers of plate-type collectors. He found that with increasing dust accumulation on the cover transmittance drops to a significant level. On the other hand, Zamfir et al. (1994) experimented the effect of cloud cover on long-term performance of flat plate solar collectors and found that during monthly general average days the performance is worse than in the mean cloudy days. However, the still should be cleaned once a week regularly to reduce the effect of dust accumulation.

Table 4 summarizes all these climatic parameters.

\section{Design of a passive solar still for Bangladesh}

It is evident from the above study that an inclined stepped solar still with passive condenser, internal and external reflectors, and black cotton wick and with optimum design values discussed above can be the desired 
still, which would give maximum yield. Initially, saline water is stored in a transparent storage tank made of glass or transparent plastic. This will preheat the water supply and will also provide domestic hot water. Then, water flow is connected with the still through a valve. Stepped layers of the still will decrease the water to glass cover distance. The inclination of the still will be $23.7^{\circ}$ facing the south. The depth of the steps could be $10 \mathrm{~mm}$, and water level could be of $5 \mathrm{~mm}$. Tables 2, 3 and 4 show the optimum values of parameters for an inclined stepped solar still. According to these values, a design of the proposed still is given in Fig. 6. This proposed still would be very easily makable and should be highly portable to be used at disaster situations and also at regular operations.

\section{Conclusion}

Because of the sea-level rise, the salinity boundary is increasing gradually at the southern part of Bangladesh. As Bangladesh is a low-lying disaster-prone country scarcity of pure drinkable water is very common. Bangladesh receives significant amount of solar energy to produce good amount of distillate from passive solar stills. In this paper, all the parameters that effect the distillate productivity of a passive solar still are analyzed and optimum parameters are chosen for a cheap and efficient design for southern part of Bangladesh. First, for design parameters number of slopes are chosen as one, number of basins should also be one. Glass cover inclination should be equal to the angle of latitude. The gap distance between water and glass cover should be minimum. To lower this gap, a stepped solar still can be used. Charcoal and rocks can be used as an energy absorption and storing material. Insulation thickness should be higher. Internal and external reflector can be added to improve the distillate productivity. Although sun tracking system will increase the efficiency but it is costly and needs a lot of maintenance, and therefore, it is not added in the proposed still. Clothes can be used as a wick material. Passive condenser is used in the design to improve the condensation performance. The optimal operational parameter values are also taken into account such as the water depth is kept minimum below $5 \mathrm{~mm}$. The water is colored with charcoal particle. The water mass flow rate is kept minimum. Lower salt concentration is recommended for higher distillate yield. PCMs are not recommended because of their lack of research output. Preheating of water is suggested by using a transparent storage tank. Although climatic parameters are not controllable, it is recommended to keep the still in an open windy space with low dust.

\section{Authors' contributions}

MNIS carried out the literature review, proposed the new solar still design and drafted the manuscript. AIS designed the still. SMSR, MSS and AIS collected field data of southern Bangladesh and done the water quality tests of those areas. All authors read and approved the final manuscript.

\section{Author details}

${ }^{1}$ Institute of Energy, University of Dhaka, Dhaka, Bangladesh. ${ }^{2}$ International Training Network Center, Bangladesh University of Engineering and Technology, Dhaka, Bangladesh. ${ }^{3}$ Bangladesh University of Engineering and Technology, Dhaka, Bangladesh.

\section{Competing interests}

The authors declare that they have no competing interests.

\section{Funding}

The work was partially funded by the International Training Network-Bangladesh University of Engineering and Technology under the project-" Sweet water pond protection in coastal area."

Received: 1 September 2016 Accepted: 28 January 2017

Published online: 15 February 2017

\section{References}

Abdallah, S., Abu-Khader, M. M., \& Badran, O. (2009). Effect of various absorbing materials on the thermal performance of solar stills. Desalination, 242(1-3), 128-137. doi:10.1016/j.desal.2008.03.036.

Abdallah, S., \& Badran, O. O. (2008). Sun tracking system for productivity enhancement of solar still. Desalination, 220(1-3), 669-676. doi:10.1016/j. desal.2007.02.047. European Desalination Society and Center for Research and Technology Hellas (CERTH), Sani Resort 22-25 April 2007, Halkidiki, GreeceEuropean Desalination Society and Center for Research and Technology Hellas (CERTH), Sani Resort.

Abu-Hijleh, B. A. (2003). Effect of water emissivity on solar still efficiency. International Journal of Sustainable Energy, 23(1-2), 13-19. doi:10.1080/01 42591031000148605

Akash, B. A., Mohsen, M. S., \& Nayfeh, W. (2000). Experimental study of the basin type solar still under local climate conditions. Energy Conversion and Management, 41(9), 883-890. doi:10.1016/S0196-8904(99)00158-2.

Al-Hinai, H., Al-Nassri, M. S., \& Jubran, B. A. (2002). Effect of climatic, design and operational parameters on the yield of a simple solar still. Energy Conversion and Management, 43(13), 1639-1650. doi:10.1016/ S0196-8904(01)00120-0.

Al-Karaghouli, A. A., \& Alnaser, W. E. (2004). Performances of single and double basin solar-stills. Applied Energy, 78(3), 347-354. doi:10.1016/ S0306-2619(03)00005-9.

Asbik, M., Ansari, O., Bah, A., Zari, N., Mimet, A., \& El-Ghetany, H. (2016). Exergy analysis of solar desalination still combined with heat storage system using phase change material (pcm). Desalination, 381, 26-37.

Bhardwaj, R., ten Kortenaar, M., \& Mudde, R. (2016). Inflatable plastic solar still with passive condenser for single family use. Desalination, 398, 151-156.

Cooper, P. I. (1972). Some factors affecting the absorption of solar radiation in solar stills. Solar Energy, 13(4), 373-381. doi:10.1016/0038-092X(72)90003-5

Dimaano, M. N. R., \&Watanabe, T. (2002). Performance investigation of the capric and lauric acid mixture as latent heat energy storage for a cooling system. Solar Energy, 72(3), 205-215.

Dunkle, R. (1961). Solar water distillation: the roof type still and the multiple effect diffusor. International Development in Heat Transfer, 5, 895-902.

El-Maghlany, W. M., El-Samadony, Y., \& Kabeel, A. (2016). Glass cover inclination angle effect on the radiation shape factor within conventional solar still. Desalination and Water Treatment, 57(38), 17722-17730.

El-Naggar, M., El-Sebaii, A., Ramadan, M., \& Aboul-Enein, S. (2016). Experimental and theoretical performance of finned-single effect solar still. Desalination and Water Treatment, 57(37), 17151-17166.

El-Samadony, Y., El-Maghlany, W. M., \& Kabeel, A. (2016). Influence of glass cover inclination angle on radiation heat transfer rate within stepped solar still. Desalination, 384, 68-77.

El-Sebaii, A. A. (2000). Effect of wind speed on some designs of solar stills. Energy Conversion and Management, 41(6), 523-538. doi:10.1016/ s0196-8904(99)00119-3. 
El-Sebaii, A. A., Al-Ghamdi, A. A., Al-Hazmi, F. S., \& Faidah, A. S. (2009). Thermal performance of a single basin solar still with PCM as a storage medium. Applied Energy, 86(7-8), 1187-1195. doi:10.1016/j. apenergy.2008.10.014.

Fath, H. E. S., \& Elsherbiny, S. M. (1993). Effect of adding a passive condenser on solar still performance. Energy Conversion and Management, 34(1), 63-72. doi:10.1016/0196-8904(93)90008-X.

Garg, H. P., \& Mann, H. S. (1976). Effect of climatic, operational and design parameters on the year round performance of single-sloped and doublesloped solar still under Indian arid zone conditions. Solar Energy, 18(2), 159-163. doi:10.1016/0038-092X(76)90052-9.

Ghoneyem, A., \& Ileri, A. (1997). Software to analyze solar stills and an experimental study on the effects of the cover. Desalination, 114(1), 37-44. doi:10.1016/S0011-9164(97)00152-5.

Gupta, B., Shankar, P., Sharma, R., \& Baredar, P. (2016). Performance enhancement using nano particles in modified passive solar still. Procedia Technology, 25, 1209-1216.

Hansen, R. S., Narayanan, C. S., \& Murugavel, K. K. (2015). Performance analysis on inclined solar still with different new wick materials and wire mesh. Desalination, 358, 1-8.

Hegazy, A. A. (2001). Effect of dust accumulation on solar transmittance through glass covers of plate-type collectors. Renewable Energy, 22(4), 525-540. doi:10.1016/S0960-1481(00)00093-8.

Kabeel, A. E., Khalil, A., Omara, Z. M., \& Younes, M. M. (2012). Theoretical and experimental parametric study of modified stepped solar still. Desalination, 289, 12-20. doi:10.1016/j.desal.2011.12.023.

Kalbasi, R., \& Esfahani, M. N. (2010). Multi-effect passive desalination system, an experimental approach. World Applied Sciences Journal, 10(10), $1264-1271$.

Kalogirou, S. A. (1996). Design and construction of a one-axis sun-tracking system. Solar Energy, 57(6), 465-469. doi:10.1016/S0038-092X(96)00135-1.

Kalogirou, S. A. (2005). Seawater desalination using renewable energy sources. Progress in Energy and Combustion Science, 31(3), 242-281. doi:10.1016/j. pecs.2005.03.001.

Kauranen, P., Peippo, K., \& Lund, P. (1991). An organic pcm storage system with adjustable melting temperature. Solar Energy, 46(5), 275-278.

Kenisarin, M., \& Mahkamov, K. (2007). Solar energy storage using phase change materials. Renewable and Sustainable Energy Reviews, 11(9), 1913-1965. doi:10.1016/j.rser.2006.05.005.

Mahdi, N. A. (1992). Performance prediction of a multi-basin solar still. Energy, 17(1), 87-93. doi:10.1016/0360-5442(92)90035-X.

Mahdi, J. T., Smith, B. E., \& Sharif, A. O. (2011). An experimental wick-type solar still system: Design and construction. Desalination, 267(2-3), 233-238. doi:10.1016/j.desal.2010.09.032.

Malik, M. A. S., Tiwari, G. N., Kumar, A., \& Sodha, M. S. (1982). Solar distillation. Oxford: Pergamon Press.

Miller, P., \& Westra, P. (1998). How surfactants work no. 0.564. Colorado State University Cooperative Extension, Crop Fact Sheet.

Minasian, A. N., \& Al-Karaghouli, A. A. (1995). An improved solar still: The wick-basin type. Energy Conversion and Management, 36(3), 213-217. doi:10.1016/0196-8904(94)00053-3.

Mishra, D. R., Tiwari, A. K., \& Sodha, M. S. (2016). Mathematical modeling and evaluation of new long single slope still for utilization of hot wastewater. Applied Thermal Engineering, 108, 353-357.

Murugavel, K. K., \& Srithar, K. (2011). Performance study on basin type double slope solar still with different wick materials and minimum mass of water. Renewable Energy, 36(2), 612-620. doi:10.1016/j.renene.2010.08.009.

NASA: Surface meteorology and Solar Energy data (2015). https://eosweb.larc. nasa.gov/sse/.

Nafey, A. S., Mohamad, M. A., \& Sharaf, M. A. (2008). Enhancement of solar water distillation process by surfactant additives. Desalination, 220(1-3), 514-523. doi:10.1016/j.desal.2007.01.051. European Desalination Society and Center for Research and Technology Hellas (CERTH), Sani Resort 22-25 April 2007, Halkidiki, Greece European Desalination Society and Center for Research and Technology Hellas (CERTH), Sani Resort.

Nagano, K., Mochida, T., Takeda, S., Domański, R., \& Rebow, M. (2003). Thermal characteristics of manganese (II) nitrate hexahydrate as a phase change material for cooling systems. Applied thermal engineering, 23(2), 229-241.
Nagano, K., Ogawa, K., Mochida, T., Hayashi, K., \& Ogoshi, H. (2004). Thermal characteristics of magnesium nitrate hexahydrate and magnesium chloride hexahydrate mixture as a phase change material for effective utilization of urban waste heat. Applied Thermal Engineering, 24(2), 221-232.

Park, B., Huh, Y. H., \& Kim, M. (2010). Surfactant additives for improved photovoltaic effect of polymer solar cells. Journal of Materials Chemistry, 20(48), 10862-10868.

Patel, P., \& Kumar, R. (2016). Comparative performance evaluation of modified passive solar still using sensible heat storage material and increased frontal height. Procedia Technology, 23, 431-438.

Phadatare, M. K., \& Verma, S. K. (2007). Influence of water depth on internal heat and mass transfer in a plastic solar still. Desalination, 217(1-3), 267-275. doi:10.1016/j.desal.2007.03.006.

Rajaseenivasan, T., Tinnokesh, A., Kumar, G. R., \& Srithar, K. (2016). Glass basin solar still with integrated preheated water supply-theoretical and experimental investigation. Desalination, 398, 214-221.

Rajvanshi, A. K. (1981). Effect of various dyes on solar distillation. Solar Energy, 27(1), 51-65. doi:10.1016/0038-092X(81)90020-7.

SRDI: Soil Resource Development Institute, Government of Bangladesh (2016). http://www.srdi.gov.bd/.

Sarı, A. (2005). Eutectic mixtures of some fatty acids for low temperature solar heating applications: Thermal properties and thermal reliability. Applied Thermal Engineering, 25(14), 2100-2107.

Sharshir, S., Peng, G., Wu, L., Yang, N., Essa, F., \& Kabeel, A. (2016). The effects of graphite nanoparticles, phase change material, and film cooling on the solar still performance. arXiv preprint arXiv:1605.01819.

Singh, S. K., Bhatnagar, V. P., \& Tiwari, G. N. (1996). Design parameters for concentrator assisted solar distillation system. Energy Conversion and Management, 37(2), 247-252. doi:10.1016/0196-8904(95)00166-B.

Singh, H. N., \& Tiwari, G. N. (2004). Monthly performance of passive and active solar stills for different Indian climatic conditions. Desalination, 168 145-150. doi:10.1016/j.desal.2004.06.180. Desalination Strategies in South Mediterranean Countries.

Soliman, S. H. (1972). Effect of wind on solar distillation. Solar Energy, 13(4), 403-415. doi:10.1016/0038-092X(72)90006-0.

Tanaka, H. (2009). Experimental study of a basin type solar still with internal and external reflectors in winter. Desalination, 249(1), 130-134. doi:10.1016/j.desal.2009.02.057

Tanaka, H. (2011). A theoretical analysis of basin type solar still with flat plate external bottom reflector. Desalination, 279(1-3), 243-251. doi:10.1016/j. desal.2011.06.016.

Tanaka, H., \& Nakatake, Y. (2006). Theoretical analysis of a basin type solar still with internal and external reflectors. Desalination, 197(1-3), 205-216. doi:10.1016/j.desal.2006.01.017.

Tiwari, A. K., \& Tiwari, G. N. (2007). Thermal modeling based on solar fraction and experimental study of the annual and seasonal performance of a single slope passive solar still: The effect of water depths. Desalination, 207(1-3), 184-204. doi:10.1016/j.desal.2006.07.011.

Velmurugan, V., Kumaran, S. S., Prabhu, N. V., \& Srithar, K. (2008). Productivity enhancement of stepped solar still: Performance analysis. Thermal Science, 12(3), 153-163.

Watmuff, J., Charters, W., \& Proctor, D. (1977). Solar and wind induced externa coefficients-solar collectors. Cooperation Mediterraneenne pour l'Energie Solaire, 1, 56.

Yari, M., Mazareh, A., \& Mehr, A. (2016). A novel cogeneration system for sustainable water and power production by integration of a solar still and pv module. Desalination, 398, 1-11.

Zamfir, E., Oancea, C., \& Badescu, V. (1994). Cloud cover influence on longterm performances of flat plate solar collectors. Renewable Energy, 4(3), 339-347. doi:10.1016/0960-1481(94)90038-8.

Zhang, T., Oyama, T., Horikoshi, S., Zhao, J., Serpone, N., \& Hidaka, H. (2003). Photocatalytic decomposition of the sodium dodecylbenzene sulfonate surfactant in aqueous titania suspensions exposed to highly concentrated solar radiation and effects of additives. Applied Catalysis B: Environmental, 42(1), 13-24. 